\title{
Acknowledgements
}

This book is the result of a study undertaken by the Constitution Unit during 2000-1. A project on Scottish independence was first conceived by Robert Hazell back in 1998. David Sinclair did the early research, and obtained funding for the project from the Esmée Fairbairn Foundation in 1999. We are very grateful for their generous support, which was essential to the project. The book which has resulted is the product of an independent initiative by the Constitution Unit which has not been influenced by any government body or political party.

The work would not have been possible without help and support from a large number of individuals. The study relied in part on study visits to Scotland, Denmark, and Quebec, and benefited hugely from the interviews conducted in the course of the research. Acknowledging the assistance of everyone involved does not in any way imply their agreement with the overall content and conclusions. Any errors remain the authors' own.

I am extremely grateful for the generous help and continued involvement of Alan and Caroline Boyle, Eileen Denza, Tony Aust, Matthew Happold, Abby Innes, Brendan O'Leary, William Walker, Louis Forget, Beth Richardson, Emmanuel Kattan, Denis Turcotte, Johanne Poirier, Jeremy Jenkins, and Simon Partridge. I am indebted to Michael Keating who produced an inspirational conclusion at very short notice and thus added an extra dimension to the book.

Thanks are also due to Martin Reid, Bill Lawton, Amanda Sloat, Elizabeth Holt, Andrew Scott, Caitríona Carter, Robert Lane, Clive Archer, James Mitchell, Neil Walker, Iain MacWhirter, Kirsty Milne, George Kerevan, John Goodlad, David Spence, Frederik Harhoff, Vibeke Roosen, Per Lachman, Árni Olafsson, Jenny Hartley, Diane Stephenson, Paula Cohen, James Cant, Richard Hogben, David Nelson, Naseef Huda, John Bachtler, Tim Figures, Karen Henderson, Heather Grabbe, Keith Patchett, Shaun Bowler, Mads Qvortrup, Angus Robertson, Neil Mac- 
Cormick, Ben Wallace, Andrew Rogerson, Natalie Lichtenstein, Gwynneth Williams, William Wallace, Romesh Vaitilingam, Quentin Thomas, and Gwynneth and Douglas Frame.

Particular thanks are owed to the interviewees in Canada: Mark Walters (and all attendants of his lunch-time discussion group), Daniel Turp, Robert Young, Warren J. Newman, Mary Dawson, Ghislain Otis, Leslie Seidle, Graham Flack, Andrew Bennett, Joël Lépine, Guy Lachapelle, Michel Venne, Yves-Marie Morissette, Jean François Gaudreault-Desbiens, Guy Laforest, Joseph Facal, Francine Barry, Michel Seymour, Serge Joyal, André Joli-Coeur, Jacques Frémont, Benoît Pelletier, Ronald L. Watts, Hudson Meadwell, Peter Leslie, Dan Soberman, as well as Fiona and Philip Mason, Joanne Bayly, Julian Feldman, and Daniel Sanger.

The Director of the Constitution Unit, Professor Robert Hazell, as well as my colleague Alan Trench read and commented on every piece of work in progress, and offered steady back up and encouragement. Roger Masterman deserves special credit for copy-editing every chapter of the book and for generally chipping in bits of information at the right moment. Other members of the Constitution Unit and the School of Public Policy at University College London offered support and help at various junctures. These included: Jeremy Croft, Meg Russell, Ben Seyd, Clare Delap, Mark Sandford, Scott Greer, Rebecca Blackwell, Gareth Lewes, as well as Allyson Pollock, Melanie Mason and James Lancaster. David Sinclair's excellent earlier research, as well as his briefing 'Issues Around Scottish Independence' (The Constitution Unit, September 1999), were invaluable and made possible the speedy completion of this project. His briefing has largely been incorporated into this work.

A seminar on Chapters 1-3 was held at Edinburgh University which was attended by David Nelson, Alex Wright, Eberhardt Bort, Simon Wakefield, Gordon Mulholland, Craig Milroy, Alasdair Allan, Robert Seaton, Stephen Tierney, Elizabeth Watson, Barry Winetrobe, Eileen Denza, Magnus Linklater, William Walker, Peter Jones and Robert Hazell. The Constitution Unit and Peter Jones would like to thank the attendants for their critical comments and useful suggestions.

Finally, thanks are due to my other colleagues, acquaintances, friends, and family. I would like to single out Arthur Schafer, Jennifer August, Romie Singh and Hans Murkens for their stimulus and subtle support.

Peter Jones has asked us to acknowledge the invaluable contributions and assistance which he has received from many sources. In particular, he would like to single out Matty Schreck for his help with sources on Czechoslovakia, and Robert Gill for his many hours of work on financial data and unearthing of material on Quebec. Thanks for advice and help are also due 
to Gavin McCrone, Jeremy Peat, Hervey Gibson, James Mitchell, Donald MacRae, Neil Hood, John McLaren, Andrew Wilson, David Bell, Dan Mulhall, Conor O'Riordan, Denis Turcotte, William Lawton, Alice Brown and Iain McNicoll. Thanks also go to staff at the National Statistics Office, the economics and statistics division of the Scottish Executive, the economics department of the Royal Bank of Scotland, and to Wood Mackenzie. An especial note of thanks is insufficient recognition of the toleration of Rhona, Peter's wife, for the many nights he spent hunched over a keyboard.

Jo Eric Murkens

The Constitution Unit

London

March 2002 


\section{Notes on the Authors}

Jo Eric Murkens worked as a Research Assistant at the Constitution Unit from September 2000 to August 2001. As the lead researcher on the Scottish Independence project he published a briefing on 'Scotland's Pace in Europe' in February 2000 and contributed the Europe section to the Unit's quarterly monitoring reports. Born in Bristol to a German father and an Anglo-Indian mother, Jo holds dual (British and German) citizenship. He went to school in Hanover and Cologne, but returned to Britain for higher education. Jo read English and European Law at Queen Mary and Westfield College, London, and the University of Copenhagen. $\mathrm{He}$ is currently a researcher at the European University Institute, Florence.

jo.murkens@iue.it

Peter Jones has been the Scotland and North of England correspondent of The Economist since 1995. Prior to that, he was the Scottish Political Editor of The Scotsman for eight years. Other publications include (with Christopher Harvie) The Road to Home Rule, a popular history of the Scottish home rule movement, published in 2000 by Edinburgh University Press, and several articles on Scottish politics in Scottish Affairs, a quarterly journal. He is an honours graduate in geography of St Andrews University. Peter lives in Edinburgh and is married to Rhona Brankin, the Labour Member of the Scottish Parliament for Midlothian since 1999. The views expressed in this and all other publications are his, and his alone.

Pjones@ednet.co.uk

Michael Keating graduated from the University of Oxford and gained his $\mathrm{PhD}$ at Glasgow College (now Glasgow Caledonian University) in 1975. He is Professor of Regional Studies at the European University Institute, 
Florence, and Professor of Scottish Politics at the University of Aberdeen. He previously taught at the universities of Strathclyde and Western Ontario and has held visiting posts in the United States, France, Spain and Norway. He has published widely in the field of regionalism, nationalism, Scottish politics, and urban politics and policy, and his most recent book is Plurinational Democracy: Stateless Nations in a Post-Sovereignty Era (Oxford University Press, 2001). 
'A functioning democracy requires a continuous process of discussion . . No one has a monopoly on truth, and our system is predicated on the faith that in the marketplace of ideas, the best solutions to public problems will rise to the top. Inevitably, there will be dissenting voices. A democratic system of government is committed to considering those dissenting voices, and seeking to acknowledge and address those voices in the laws by which all in the community must live.'

The Supreme Court of Canada, Reference re Secession of Quebec [1998] 2 S.C.R. 217, paragraph 68.

'It should be borne in mind that there is nothing more difficult to arrange, more doubtful of success, and more dangerous to carry through than initiating changes in a state's constitution. The innovator makes enemies of all those who prospered under the old order, and only lukewarm support is forthcoming from those who would prosper under the new. Their support is lukewarm partly from fear of their adversaries, who have the existing laws on their side, and partly because men are generally incredulous, never really trusting new things unless they have tested them by experience. In consequence, whenever those who oppose the changes can do so, they attack vigorously, and the defence made by others is only lukewarm. So both the innovator and his friends are endangered together.'

Niccolo Machiavelli, The Prince, Chapter VI

'Politics is perhaps the only profession for which no preparation is thought necessary.'

Robert Louis Stevenson (1850-1894),

'Yoshida-Torajiro,'

Familiar Studies of Men and Books, 1882. 